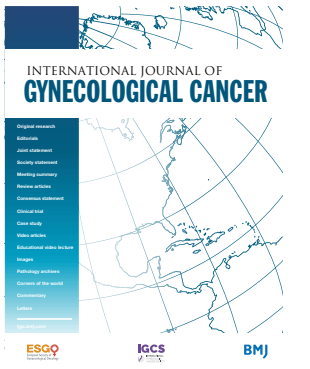

- Additional supplemental material is published online only. To view, please visit the journal online (http://dx.doi.org/ 10.1136/ijgc-2021-002631).

For numbered affiliations see end of article.

\section{Correspondence to} Dr Antonio Braga, Obstetrics and Gynecology, Federal University of Rio de Janeiro, Rio de Janeiro 22240-003, Brazil; bragamed@yahoo.com.br

Accepted 26 April 2021 Published Online First 28 May 2021

\title{
Treatment of hydatidiform mole using manual vacuum aspiration: technical and tactical aspects
}

Antonio Braga (DD , ${ }^{1,2}$ Lilian Padrón, ${ }^{3}$ Jorge Rezende-Filho, ${ }^{1}$ Kevin Elias, ${ }^{4}$ Neil Horowitz, ${ }^{4}$ Ross Berkowitz ${ }^{4}$

Hydatidiform mole (HM) represents the benign spectrum of gestational trophoblastic disease (GTD), an abnormal pregnancy characterized by aberrant fertilization of the oocyte. ${ }^{1}$ The treatment of $\mathrm{HM}$ is uterine evacuation, usually done through electric vacuum aspiration (EVA). However, numerous conditionsincluding legal, religious, and economic-prevent several countries from having access to the devices used to perform EVA. In Brazil the vast majority of GTD Reference Centers do not have EVA, so more than 70\% of $\mathrm{HMs}$ are treated with manual vacuum aspiration (MVA). ${ }^{2}$ The aim of this video article is to present a representative case where MVA is used for evacuation of HM (Video 1).

After approval by the Rio de Janeiro Federal University Institutional Review Board in February 2021 (number: 4.555.188) and obtaining written informed consent from the patient, we describe a case of a patient at 12 weeks gestation who was referred to our institution due to bleeding, uterus larger than gestational age, human chorionic gonadotropin of $178678 \mathrm{IU} / \mathrm{L}$, and ultrasonography suggesting HM. She underwent uterine MVA for the treatment of a molar pregnancy.

\section{INTERSATIONAL OOURNAL OF}

Treatment of hydatidiform mole using manual vacuum aspiration Technical and tactical aspects

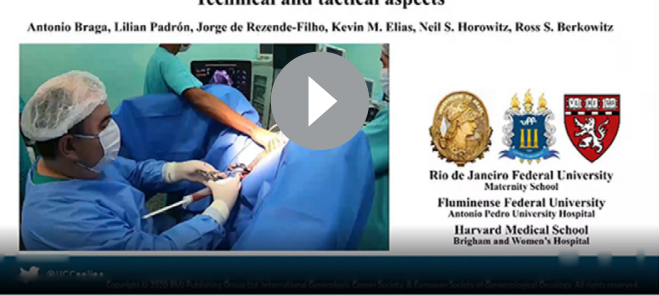

Video 1 Uterine evacuation by manual vacuum aspiration guided by ultrasonography for the treatment of hydatidiform mole. This video shows that manual vacuum aspiration can replace electric vacuum aspiration in settings that do not have electrical equipment formolar evacuation. This simple, effective, and inexpensive method can be a safe alternative for uterine evacuation in cases of hydatidiform mole.
In the video we show the MVA technique for the treatment of $\mathrm{HM}$, as well as strategies to make the surgery safer and more effective (see also online supplemental tables 1 and 2). There are two important tips for performing molar MVA: the first is to have two aspiration syringes, which makes the procedure more efficient, and the second is to perform cervical dilation with the plastic cannulas themselves, minimizing the risk of perforation. ${ }^{3}$ Ultrasonography guidance during the procedure assists in monitoring uterine evacuation, avoiding uterine perforation, and helping to ensure complete evacuation. When the contents of the syringe become pink and bullous, it is a sign that the uterine cavity is empty. ${ }^{4} \mathrm{~A}$ gentle uterine sharp curettage after molar evacuation is important to remove any adherent trophoblastic tissue remnants.

\section{Author affiliations}

${ }^{1}$ Department of Obstetrics and Gynecology, Federal University of Rio de Janeiro, Rio de Janeiro, Rio de Janeiro, Brazil ${ }^{2}$ Department Maternal Child, Federal Fluminense University, Niteroi, Rio de Janeiro, Brazil

${ }^{3}$ Gynecology Institute, Federal University of Rio de Janeiro, Rio de Janeiro, Brazil

${ }^{4}$ Department of Obstetrics and Gynecology, Division of Gynecologic Oncology. Brigham and Women's Hospital, Harvard Medical School, Boston, Massachusetts, USA

Twitter Antonio Braga @BragaDTG

Contributors AB: Surgeon, development of paper, review of the literature. LP: Surgeon, development of paper, review of the literature. JR-F: Ultrasonographer, development and review of paper. KE, NH, RB: Development and review of paper. All authors approved the final version.

Funding This research was supported by the National Counci for Scientific and Technological Development - CNPq (AB), Donald P. Goldstein MD Trophoblastic Tumor Registry Endowment and the Dyett Family Trophoblastic Disease Research and Registry Endowment (KME, NSH, RSB).

Competing interests None declared.

Patient consent for publication Not required.

Provenance and peer review Not commissioned; externally peer reviewed. 


\section{Video article}

Data availability statement All data relevant to the study are included in the article or uploaded as supplementary information.

Supplemental material This content has been supplied by the author(s). It has not been vetted by BMJ Publishing Group Limited (BMJ) and may not have been peer-reviewed. Any opinions or recommendations discussed are solely those of the author(s) and are not endorsed by BMJ. BMJ disclaims all liability and responsibility arising from any reliance placed on the content. Where the content includes any translated material, BMJ does not warrant the accuracy and reliability of the translations (including but not limited to local regulations, clinical guidelines, terminology, drug names and drug dosages), and is not responsible for any error and/or omissions arising from translation and adaptation or otherwise.

ORCID iD

Antonio Braga http://orcid.org/0000-0002-2942-6182

\section{REFERENCES}

1 Elias KM, Berkowitz RS, Horowitz NS. State-Of-The-Art workup and initial management of newly diagnosed molar pregnancy and postmolar gestational trophoblastic neoplasia. J Natl Compr Canc Netw 2019;17:1396-401.

2 Braga A, Moraes V, Maestá I, et al. Changing trends in the clinical presentation and management of complete hydatidiform mole among Brazilian women. Int J Gynecol Cancer 2016;26:984-90.

3 Padrón L, Rezende Filho J, Amim Junior J, et al. Manual compared with electric vacuum aspiration for treatment of molar pregnancy. Obstet Gynecol 2018;131:652-9.

4 Braga A, Padrón L, Balen JL. Video hysteroscopy in the diagnosis of molar pregnancy in two challenging situations: complete mole with normal hCG and partial mole with early gestational age. J Minim Invasive Gynecol 2021;S1553-4650:00081-9. 